\title{
Fermentation of sugarcane juice and blackstrap molasses by Zymomonas mobilis'
}

\author{
Henry Huertas-Diaz," Carmen L. Cachor and Luis Bernard" \\ ABSTRACT
}

The batch fermentation of $10^{\circ}$ Brix sugarcane juice and blackstrap molasses was accomplished by two strains of $Z$. mobilis. The substrates were desalted by filtration through cation resins to decrease their mineral content. The mineral concentration and chemical preservatives present inthe substrates did not inhibit the fermentation. Both strains produced fewer by-products when blackstrap molasses was used as substrafe. Byproducts other than levan and sorbitol were identified by high performance liquid chromatography (HPLC) and gas chromatography mass spectometry (GC/MS) analyses.

\section{RESUMEN}

Fermentación del guarapo y la melaza de caña por Zimomonas mobilis

Dos cepas de la bacteria Zymomonas mobilis fermentaron soluciones a $10^{\circ}$ Brix de guarapo de caña de azúcar y miel final. Los minerales y preservativos químicos presentes en la miel final no inhibieron la fermentación. En trabajos previos realizados con mieles de caña de azúcar se había sugerido la posibilidad de una inhibición de la fermentación causada por estas sustancias.

El guarapo y la miel final se filtraron en resinas de intercambio catiónico para disminuirles el contenido de minerales. Sin embargo, las cepas B-1 y B.5 produjeron más alcohol en los sustratos que las que no se filtraron en resinas.

El etanol producido y analizado por HPLC sobrepaś́ los valores teóricos máximos de producción de alcohol. Al analizar por GC/MS se identificaron los subproductos acetoína, acetaldehído y ácido acético. Estos subproductos posiblemente causaron la interferencia durante el análisis de etanol por HPLC.

\section{INTRODUCTION}

Zymomonas mobilis is a gram negative bacteria which ferments sugars through the Entner-Doudoroff pathway $(2,9,14)$. It is known for the production of pulque and cactus and palm wines $(3,9)$. It has been used to ferment a varriety of fruit substrates $(6,7)$. When it is compared with Saccharomyces cerevisiae, the yeast responsible for almost all the alcohol production in the world, it has a higher ethanol rate of production, and the same ethanol yield and tolerance $(10,14,15,19)$. Unlike yeasts,

\footnotetext{
'Manuscript submitted to Editorial Board 5 July 1990.

2Research Assistant, Rum Pilot Plant.

${ }^{3}$ Associate Researcher, Rum Pilot Plant.

${ }^{4}$ Research Assistant, Central Analytical Laboratory.
} 
$Z$. mobilis has a limited substrate range; it ferments only sucrose, glucose and fructose (3). These three sugars are the only ones present in sugarcane products, the most abundant substrate for alcoholic fermentation in the Caribbean region.

The fermentation of sugarcane molasses with $Z$. mobilis has been accomplished in the last decade with relative success. Low ethanol rate of production was obtained during the fermentation of high test molasses and blackstrap molases $(10-13,18)$. This low ethanol production was considered to be a direct effect of the excess of minerals present in the molasses. As a result the removal of minerals from the molasses has been tested in several ways and it is considered as an alternative for the molasses fermentation when $Z$. mobilis is used as fermenter (10). However, Lefebvre et al. considered that only the minerals exerted an inhibitory effect over the bacteria. However, the effect of chemical preservatives, antibiotics and osmotic pressure should also be considered.

In the experiments reported here, blackstrap molasses and sugarcane juice were fermented by $Z$. mobilis without the previously reported inhibitory effects. The efficient fermentation of blackstrap molasses discards the possibility of inhibitory effects by the mineral content and the chemical preservatives, if any, in the molasses. The strain selection and a low initial sugar concentration have been found to be important in the fermentation of this complex substrate. The ethanol produced was determined by HPLC. Consistently, values higher than the predicted theoretical values were obtained. Preliminary results suggest that the by-products mannitol, acetoin, acetaldehyde and acetic acid probably account for these higher ethanol values.

\section{MATERIALS AND METHODS}

The bacteria used were Zymomonas mobilis (ATCC 31821) and Z. mobilis subsp. mobilis (ATCC 10988). These bacteria are reported here as strains B-5 and B-1, respectively. The strains were maintained in broth cultures containing $2.0 \%$ dextrose as carbon and energy source with $1.0 \%$ yeast extract and $0.2 \% \mathrm{KH}_{2} \mathrm{PO}_{4}$ for the strain $\mathrm{B}-5$, and $0.5 \%$ yeast extract for the strain B-1. These broths were used as a seed. The pH was adjusted with $7 \mathrm{~N} \mathrm{NaOH}$ or conc. $\mathrm{H}_{2} \mathrm{SO}_{4}$ to 5.0 and the incubation time was $48 \mathrm{~h}$ at $30^{\circ} \pm 0.5^{\circ} \mathrm{C}$. These conditions were held constant, as well as the proportions of yeast extract and $\mathrm{KH}_{2} \mathrm{PO}_{4}$ for each strain, during the experiments.

The fermentation worts prepared at $10^{\circ}$ Brix in duplicates were blackstrap molasses and desalted blackstrap molasses as well as sugarcane juice and desalted sugarcane juice. All media were sterilized by Autoclave at $121^{\circ} \mathrm{C}$ and $15 \mathrm{psi}$ in. for $15 \mathrm{~min}$. The inoculum $(10 \mathrm{ml}$ of seed) was added to $90 \mathrm{ml}$ of those worts. After $48 \mathrm{~h}$, samples were taken and analyzed by high performance liquid chromatography (HPLC) for 
levan, sucrose, glucose, fructose, sorbitol and ethanol content. The $\mathrm{HPLC}$ analysis were conducted at $75^{\circ} \mathrm{C}$ with a Sugar-Pack column with deionized water as mobile phase with $0.6 \mathrm{ml} / \mathrm{min}$ flow. The results in tables 2 and 3 show the average of the duplicate samples analyzed.

Those samples in which the ethanol content exceeded the theoretical value were distilled and analyzed by gas chromatography-mass spectrometry (GC/MS). For gas chromatography we used a Supelcowax 10; fused silica capillary column, $30 \mathrm{~m}$ long, $0.25 \mathrm{~mm}$ ID and $0.1 \mu \mathrm{m}$ film thickness. Helium was used as a carrier gas at $30 \mathrm{ml} / \mathrm{min}$ flow. A $2.0 \mu \mathrm{l}$ sample (30:1 split) was injected while the temperature of the injector was $200^{\circ} \mathrm{C}$. The oven was programmed at $50^{\circ} \mathrm{C}$ for $6 \min$ to $150^{\circ} \mathrm{C}$ at $15 \% \mathrm{~min}$, with a holding time of $18 \mathrm{~min}$. A mass spectrometer was used as a detector with a full scan mode. The scanning and multiplier ranges were from 17 to 250 amu and 1800 volts, respectively.

The sugarcane juice and blackstrap molasses were diluted with deionized distilled water. The worts were desalted by filtration throughout a two resin column. A crystal buret (1 inches in diameter and 12 inches long) was filled with two cation exchange resins. Equivalent amounts of Dowex HCR-W2 (at the bottom) and Amberlite IRC-718 (at the top) resins were layered in the column. The worts were analyzed for the $\mathrm{Ca}^{2+}$ and $\mathrm{Mg}^{2+}$ contents by atomic absorption spectrophotometry and for the $\mathrm{K}^{+}$content by emission spectrophotometry before and after the filtration with a Perkin-Elmer 2380 Atomic Absorption Spectrophotometer. Table 1 shows the average of the triplicated samples analyzed.

\section{RESULTS}

The mineral content of sugarcane juice and molasses was reduced by filtration through cation exchange resins. These resins also reduced the sucrose content in both substrates by 10 to $20 \%$ (tables 1 and 2). The mineral and sugar contents were different in these sugarcane products at the same concentration of $10^{\circ}$ Brix.

Reduction of the cation concentration in these substrates did not affect the fermentation. Both untreated and desalted substrates were fermented completely by strain B-5. The two tested strains produced more ethanol with the untreated substrates than in the fermentation of desalted substrates.

The fermentation behavior of the strains was different for each substrate (table 3). Strain B-1 left a considerable amount of unused substrate in the blackstrap molasses fermentation and produced less ethanol in this substrate than strain B-5. The amounts of ethanol determined by HPLC were higher for strain B-1 in sugarcane juice than for B-5.

The formation of the by-producis levan and sorbitol followed the same pattern. Both strains produced less of these by-products when blackstrap molasses was the substrate. Strain B-1 used 6 to $13 \%$ of the fructose from 
TABLE 1.-Mineral content of desalted sugarcane juice and blackstrap molasses at $10^{\circ}$ $B$ Brix

\begin{tabular}{lcrrr}
\hline & & \multicolumn{3}{c}{ Minerals } \\
\cline { 3 - 5 } Substrates & Resin & \multicolumn{1}{c}{ K } & Ca & Mg \\
\hline Sugarcane juice & Control & 1253 & 36 & 39 \\
& Amb/Dowex & 14 & 2.3 & 1.5 \\
Blackstrap molasses & & & & \\
& Control & 3503 & 699 & 383 \\
& Amb./Dowex & 33 & 81 & 3.0 \\
\hline
\end{tabular}

Data in $\mathrm{p} / \mathrm{m}$.

sucrose to produce levan in sugarcane juice, and only 4 to $6 \%$ in the blackstrap molasses. However, strain B-5 used $27 \%$ of the fructose to produce sorbitol from sugarcane juice, but 10 to $13 \%$ from blackstrap molasses.

For both strains, the ethanol produced during the fermentation of sugarcane juice surpassed the theoretical values. The analysis done by HPLC showed a probable interference. Acetoin, acetaldehyde and acetic acid were identified by GC/MS analysis. Even though the amounts were not determined, these by-products probably caused interference with the HPLC analysis of ethanol. Mannitol was also detected by the HPLC analysis (data not shown).

\section{DISCUSSION}

The bacteria $Z$. mobilis should ferment sugarcane molasses without inhibition. The carbohydrate content in the molasses matches perfectly with the fermentable substrates used by these bacteria. Our results contrast with previous works in which the fermentation of this substrate with $Z$. mobilis was not accomplished successfully, or where previous molasses treatment was needed $(10,13,18)$. The probable explanations for the results were the mineral concentrations, chemical preservatives and herbicides present in the molasses.

TABLE 2.-Fermentable carbohydrate content of sugarcane juice and blackstrap molasses at $10^{\circ} \mathrm{Brix}$

\begin{tabular}{ccccc}
\hline & & & Substrates & \\
\cline { 3 - 5 } Carbohydrates & $\begin{array}{c}\text { Sugarcane } \\
\text { juice }\end{array}$ & $\begin{array}{c}\text { Desalted sugar } \\
\text { cane juice }\end{array}$ & $\begin{array}{c}\text { Blackstrap } \\
\text { molasses }\end{array}$ & $\begin{array}{c}\text { Desalted sugar } \\
\text { blackstrap } \\
\text { molasses }\end{array}$ \\
\hline Sucrose & 7.89 & 6.24 & 4.05 & 3.62 \\
Glucose & 0.32 & 0.38 & 0.91 & 0.99 \\
Fructose & 0.24 & 0.33 & 1.00 & 1.09 \\
Total & 8.45 & 6.95 & 5.96 & 5.70 \\
\hline
\end{tabular}

${ }^{1}$ Data given in $\mathrm{g} / 100 \mathrm{ml}$. 
TABLE 3.-Fermentation of sugarcane juice and blackstrap molasses by two strains of $\mathrm{Z}$. mobilis

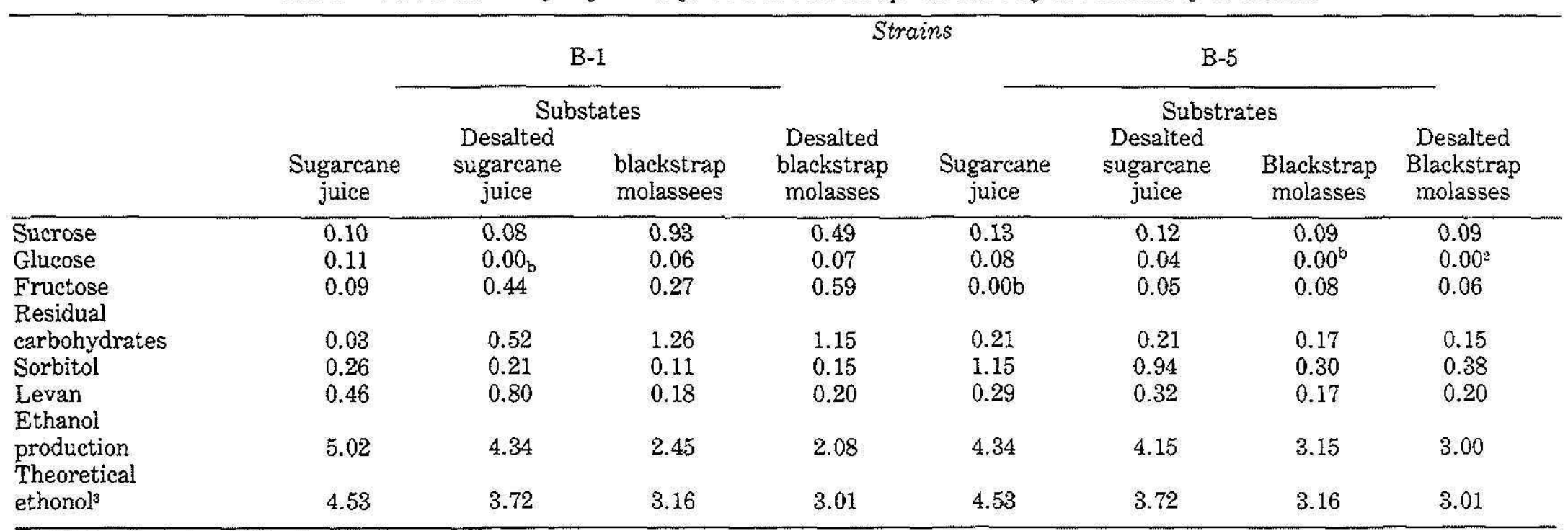

Data given in $\mathrm{g} / 100 \mathrm{ml}$.

${ }^{2}$ Amounts of less than $0.03 \mathrm{~g} / 100 \mathrm{ml}$ were counted as $0.00 \mathrm{~g} / 100 \mathrm{ml}$.

3The theoretical ethanol production was calculated as in (5) and (7). 
It is known that $Z$. mobilis will not ferment media containing $20 \mathrm{~g} / 1$ salts or more (3). The most abundant cations present in the molasses (potassium, calcium and magnesium) did not reach such a concentration at the dilutions at which the fermentation is normally carried out. Blackstrap molasses had a composition of 7 to $15 \%$ sulphate ash at $57^{\circ}$ Brix (11). The concentration of the minerals determined by absortion spectrophotometry (table 1) could be estimated as $26 \mathrm{~g} / \mathrm{L}$ at this Brix concentration. In order to be fermented, molasses has to be diluted to a solution of $10^{\circ}$ to $20^{\circ}$ Brix. The mineral concentration at these fermentable dilutions varies from 4.6 to $9.2 \mathrm{~g} / \mathrm{L}$, far from the inhibitory mineral concentration. A mineral concentration of $20 \mathrm{~g} / \mathrm{L}$ is reached in a $44^{\circ}$ Brix blackstrap molasses solution. Under these circumstances ethanol production would probably be most affected by the increase in osmotic pressure exerted by the substrate.

Fresh sugarcane juice with no chemical preservative was fermented by both strains of $Z$. mobilis. If any chemical preservative was present in the molasses it did not affect the fermentation. No fermentation inhibition was observed.

Strain B-1 left $20 \%$ of the substrate unused during the $48 \mathrm{~h}$ of the molasses fermentation. This high amount of sucrose left unused suggests the poor rate of hydrolysis by the enzyme levan sucrase in this substrate. This poor enzyme activity does not correspond with previous reports (4). It must be mentioned that this strain was isolated from fermenting agave juice (17) and that it is not a natural cane molasses fermenter. However, during the sugarcane juice fermentation, strain B-1 produced more ethanol than strain B-5 (table 3). Strain B-1 is a levan producer and the quantity produced, as reported before $(2,7)$, was about $10 \%$ of the sucrose content.

The high ethanol yield in molasses by strain B-5 was not surprising. This strain was isolated from fermenting cane molasses in Brazil $(3,18)$.

The production of sorbitol by strain B-5 was $27 \%$, approximately one half the amount generated from fructose reported by others (16). This by-product probably acts as a compatible solution in response to the osmotic pressure, as occurs with many other microorganisms.

The production of ethanol as determined by HPLC surpassed the theoretical values by the analysis of the fermented sugarcane juice. Values exceeding the theoretical values estimated for ethanol (6) and $\mathrm{CO}_{2}$ (1) have been reported in fermentations with $Z$. mobilis. We suspect by-products as the cause of interference with results in these higher than expected ethanol yields.

By-products other than levan and sorbitol were identified by HPLC and GC/MS techniques. Mannitol, a six straight-chair carbon alcohol like sorbitol, is synthesized from fructose (9) and acts as a compatible solute in response to this monomer concentration. The presence of acetoin and 
acetaldehyde among the fermentation products has been reported previously $(3,6,17,20)$ and has been associated with the maintenance of the redox balance when sorbitol is produced (18). Production of acetic acid has also been reported before for some Zymomonas strains (3). The substances interfere with the ethanol determination during the HPLC analysis (manuscript in preparation).

Sugarcane products (blackstrap molasses, high test molasses and sugarcane juice) should not be discarded as viable substrates for ethanol production when $Z$ ymomonas mobilis is the fermenter. We are currently working to develop strains of Zymomonas mobilis and to implement a large scale process for the bacterial fermentation of these readily abundant substrates.

\section{LITERATURE CITED}

1. Agrawal, P. and U. K. Veeramallu, 1986. The Effect of $\mathrm{CO}_{2}$ ventilation on kinetics and yields of cell-mass and ethanol in batch cultures of $Z$. mobilis. Biotechnol. Letters 8 (11): 811-16.

2. Dawes, E. A., D. W. Ribbons and D. A. Rees, 1966. Sucrose utilization by $Z$. mobilis: formation of a levan. Biochem. J. 98: 804-12.

3. DeLey, J. and J. Swings, 1977. The biology of Zymomonas. Bacteriol. Rev. 41: 1-46.

4. Doelle, H. W. and E. W. Lyness, 1983. Levansucrase from Z. mobilis. Biotechnol. Letters 5 (5): 345-50.

5. - - and $\longrightarrow, 1981$. Fermentation patterm of sucrose to ethanol conversions by $Z$. mobilis. Biotechnol. Bioeng. 23: 1449-460.

6. Drainas, C., G. Kolios, M. Lekka and M. A. Typas, 1989. Bioconversion of fruit and sugar beet extracts by $Z$. mobilis to ethanol and other fine chemicals. J. Ferm. Bioeng. 67 (5): 363-65.

7. — A. A. Koutinas, M. Kanellaki and M. A. Typas, 1986. Raisin: a suitable raw material for ethanol production using Z. mobilis. Biotechnol. Letters 8 (7): 517-20.

8. Eveleigh, D. E., S. E. Buchholz and M. M. Dooley, 1987. Zymomonas -an alcoholic enigma. Trends Biotechnol. 5: 199-204.

9. - - H. W. Stokes, E. Dally, D. T. Spaniel, R. L. Williams and B. S. Montenecourt, 1981. Zymomonas: the phantom ethanol producer. Biosources Digest 3:124-32.

10. Lefebvre, M. F., S. K. Phee, R. J. Pagán, L. Wong and P. L. Rogers, 1984. Ethanol production from desalted molasses using $S$. uvarum and $Z$. mobilis. J. Ferment. Technol. 62 (3): 297-300.

11. Murphy, N. F. 1988. Batch Fermentation patterns for different strains of Zymomonas in high test molasses and blackstrap molasses. J. Agric. Univ. P.R. 72 (3): 475-81.

12. - 1988. Ethanol production from blackstrap molasses by $Z$. mobilis and Sac charomyces sp. J. Agric. Univ. P.R. 72 (3): 483-84.

13. - 1988. Z. mobilis batch and fed-batch fermentation of high test molasses. J. Agric. Univ. P.R. 72 (3): 485-88.

14. Rogers, P. L., D. Phil, K. J. Lee, M. E. Tribe and D. E. Tribe, 1980. High productivity ethanol fermentations with $Z$. mobilis. Process Biochem. (August/September): 7-11.

15. — , K. J. Lee and D. E. Tribe, 1979. Kinetics of alcohol production by $Z$. mobilis at high sugar concentrations. Biotechnol. Letters 1; 165-70.

16. Scopes, R. K. and K. Griffiths-Smith, 1986. Fermentation capabilities of $Z$. mobilis glycolytic enzymes. Biotechnol. Letters 8 (9): 653-56. 
17. Skotnicki, M. L., K. J. Lee, D. E. Tribe and P. L. Rogers, 1981. Comparison of ethanol production by different Zymomonas strains. Appl. Environ. Microbiol. 41 (4): 88993.

18. van Vuuren, H. J. J. and L. Meyer, 1982. Production of ethanol from sugarcane molasses by $Z$. mobilis. Biotechnol. Letters 4 (4): 253-56.

19. Verachtert, H. and G. Amin, 1982. Comparative study of ethanol production by immobilized-cell system using Z. mobilis and S. bayanus. Eur. J. Appl. Microbiol. Biotechnol. 14: 59-63.

20. Wills, C., P. Kratofil, D. Londo and T. Martin, 1981. Characterization of the two alcohol dehydrogenases of $Z$. mobilis. Arch. Biochem. Biophys. 210 (2): 775-85. 